\title{
NOTE ON SOEDJATMOKO'S RECOLLECTIONS OF A HISTORICAL MOMENT: SJAHRIR'S REACTION TO HO CHI MINH'S 1945 CALL FOR A FREE PEOPLES FEDERATION ${ }^{1}$
}

\author{
Hanna Papanek
}

In November 1984, in the course of one of our many conversations during the nearly twenty years I knew him, Soedjatmoko-Koko-spoke about his friend Harold Isaacs, then a Professor at M.I.T., and told me a story involving Ho Chi Minh and Sutan Sjahrir that I found so remarkable that I made some notes immediately afterwards. Although a different outcome to this story might have changed the course of history, I have no personal recollection of discussing such a possibility with Koko. He would presumably have dealt with these events more fully in his memoirs-the memoirs that Harold Isaacs and I, among others, were always urging him to write-but these memoirs will now never be written. For this reason, I have pursued further some of the details of this story and present them here for the historical record. For the same reason, I have also mentioned the incident briefly in some of the memorial articles I have written elsewhere about Soedjatmoko. ${ }^{2}$ Historians of both Indonesia and Vietnam, and perhaps India, may want to seek details from other sources but here is the story as I know it.

In 1945, the late Harold Isaacs, then covering the Asian Revolutions for Newsweek magazine, carried a letter from Ho Chi Minh, his "Shanghai friend of long ago," to the leaders of the Indonesian nationalist revolution in Java. ${ }^{3}$ Isaacs had been barred from returning to China by the "Kuomintang government ... not having approved particularly some of my reports from that country," 4 but he had continued to travel throughout the region, including Korea, Japan, the Philippines, Indochina, Siam, Malaya, and Java, as described in some detail in No Peace for Asia.

In this book, Isaacs also describes his conversations with Ho Chi Minh about Asian revolutions and the role of the Great Powers (see especially pp. 163-76)-conversations that provide some of the background for the documents that he was asked to carry to Java. Isaacs reports that, while Ho Chi Minh felt that "the Viet Nam Republic could count on relative cohesiveness [because] the dangers of internal conflict were small,"5 Viet Nam would need outside help to survive as an independent state. At the time, they could not count on the Chinese although that might change in the future. As for the Russians, Isaacs reports that he met "no Annamite," including many Communists, who thought the Russians would help their cause. The small group of French Communists in Indochina, who might have been expected to support it, instead issued a document warning the Indochinese Communist Party that they should be sure that their struggle "meets the requirements of Soviet policy." 6 Under the circumstances reported by Harold

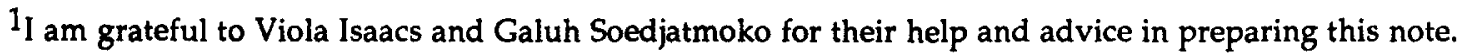

2 See Tempo, January 6, 1990, and Economic and Political Weekly, with Goenawan Muhamad, forthcoming.

${ }^{3}$ Harold Isaacs, No Peace for Asia (New York: Macmillan, 1947; Paperback edition, Cambridge, Mass.: M.I.T. Press, 1967), p. 163.

${ }^{4}$ Ibid., p. vii.

5Ibid., p. 170.

6Ibid., p. 173. 
Isaacs, it is not surprising that Ho Chi Minh turned to the leaders of the new nationalist revolutions in southern Asia with the proposal outlined in the documents reproduced below (from the Harold R. Isaacs Papers in the M.I.T. Archives). I have no information as to whether similar letters went to other Asian leaders, but this again is a point to be

pursued by historians.

Bộ NGOẠI-GIAO

Só

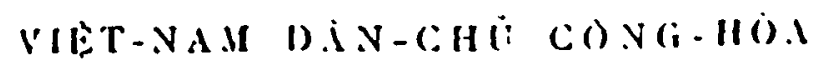

Do)C-LAP - TUP(D) - IIANII-PHÚC

Bano1

Nov. 17,1945

To the President of the Republic of Indonesia

My dear frlend:

In the present struggle which we are waging against forelgn domination, our two peoples are bound in a common cause which no force can reaken.

I take this opportunity to propose to you that viet Nam and Indonesia make a public declaration of their complete solidarity in their present struggle for freedom, at the same tIme appealing jolntiy to Indta, Burma, and Malaya and all the subject pooples of Asia to join us in a common front.

Confldent in the justice of our cause, I propose we show all the Great Powers of the world that nothing can break down our unanimous determination to light and to keep on lighting for our liberation.

To this end we propose the formation of a Preparation' Commission with the ultimate purpose of creating a Pederation; of the Pree Peoples of Southern AB1a. I am confident that ino a proposal, coming jointly from our two peoples, w1Il not fail to araken the ridest response.

Here in Viet Nam we continue and shall continue to eight to the bitter end. He extend to you our warmest greetings and our wismes for your victory in our common cause.

Yours sincerely,

HD Ch2 Minh President of the Provisional Bevernment of the People's Republic of Viet Nam. 
BO NGOẠI-GIAO

$$
\text { So }
$$

VIET-NAM DÁN-CHÜ CONG-HOAA BOCLLAP - TU.DO - HASNH.PHÚC

iroposed Text of Common Juclaration by Vlet Vam anc Indoneala

1. Wo the peoples of Indonesis and V1et llam proclaim to the vorld our complete solicarity in our comcon struggle for our comon cause: Iiberation and independence from forelon domination.

2. We jolntly appeal to the peoples of India, Burma, Lalaya and all colonial Asie to joln us in tals sacred strugble for 11fe, I1berty, and the pursuit of bapplness.

3. It 18 erldent, from the actions of Great Britain on the battlefronts of Indochlna and Inconesia and Irom the silence of all the otber Great yorers in the face of the efforts of jrance and Holland to remestablish their emplres by force. that wo must depend on ourselves and ourselves alone to vin our freedom.

4. It seems no less orldent nor that all the fine phrasea and clittering promises made by shtgreat Porers during the rax were nothyng-but empty rords meant to decelte the peoples of tha rorld, especially those peoples who heve jot to rin for themselras the most elementary liberty of self-determination.

5. We deolare to all the pooples or the world thet for us the vords justice and freedom and self-determination et1II hare. some mean1ng. that they can be translated into real ilfo Instead of remalning lies on scraps of paper medtten by scheming politiens and would-be masters.

6. Te appeal to the peoples of India, Burma, and dialaye to join us in a proparetory Comalssion to meet at the earliest possible moment, pith a rior to creating a Pederation of free Peoples of southern Asia, to forr a comson front in the present struggles and to join hands for the building of our cownon future. 
According to Koko's recollection in 1984, the letter from Ho Chi Minh went to Mohammad Hatta (whom Ho had apparently met in 1929, according to a member of the Soedjatmoko family). Hatta passed it on to Sutan Sjahrir who was then prime minister. (Sjahrir had become prime minister of Indonesia's first parliamentary government in November 1945 and, according to Viola Isaacs, Harold Isaacs was in Java in early or midDecember 1945. According to a member of the Soedjatmoko family, Koko had been asked by Amir Sjarifuddin, minister of information in the Sukarno government, to help him set up the foreign section of that Ministry. Koko's primary task was to talk to foreign correspondents, and it was in that capacity that he met Harold Isaacs on his visit to Java. This was the beginning of a life-long friendship.)

Sjahrir discussed the offer with Koko but told him he would not answer the letter and would just ignore it. Koko recalled that he was bitterly disappointed and asked why. Sjahrir replied that the Indonesian nationalists were facing the Dutch who were a weak colonial power and would be quickly defeated. He argued that "our revolution is based on nationalism and our movement contains mainly nationalists." On the other hand, according to Koko's memory of Sjahrir's argument, "Ho Chi Minh is facing the French who will resist him for a very long time. Ho is also dependent on the support of the Communists who are very powerful in the independence movement which is not the case with us." Sjahrir concluded by saying that "if we ally ourselves with Ho Chi Minh, we will weaken ourselves and delay independence." Koko, then a young and passionately idealistic activist, argued that this was a betrayal of the greater Asian Revolution. Sjahrir was not persuaded and never answered the letter. According to a member of the Soedjatmoko family, Koko later felt that history had proved Sjahrir right.

For Koko, this was obviously a very important memory for he referred to it on other occasions, including our last conversations in New York in late October 1989, a few weeks before his death. He also discussed it with members of his family and other friends in conversations that I hope they will wish to publish in the future. 